\title{
Safe lighting of pedestrian crossings
}

Abstract. This paper solves the lighting of pedestrian crossings. This type of lighting helps to improve the safety of pedestrians in this conflict area (means a pedestrian crossing).

The research was drawn on the basis of measurements of 87 pedestrian crossings in district Ostrava because the regularities can be better understood. Pedestrian crossings were evaluated on the basis of luminance ratio and statistical data of accident rate.

This paper also solves the reflectance of clothes which is also important for this research.

Keywords: pedestrian crossing, safety, measurements, luminance, accident rate, reflectance of clothes.

\section{Úvod}

Během roku 2014 bylo provedeno rozsáhlé měření na osvětlených přechodech pro chodce na území okresu Ostrava. Byly vybrány přechody, které byly realizovány $v$ období 2010 až 2012. Na těchto přechodech bylo v nočních hodinách, tak abychom vyloučili vliv denního světla, provedeno měření, které se zaměřovalo na jasové poměry na a $v$ blízkosti přechodu pro chodce. Byly měřeny jasy a osvětlenosti. Dále byly zaznamenávány geometrické údaje, stavební opatření, výskyt světelné signalizace a zástavby okolí. Údaje o osvětlovací soustavě byly zaznamenány z pohledu použití světelných zdrojů a využití doplňkového signalizačního zařízení.

\section{Dopravní nehodovost}

Při vyhodnocování je postupováno následovně. Nejprve bylo na území okresu Ostrava vytipováno místo, kde již minimálně $v$ období jednoho roku bylo nainstalováno bezpečnostní opatření. Dále byly shromážděny datové soubory, které obsahovaly informace o počtu dopravních nehod. $Z$ těchto dat byl vybrán statistický vzorek $v$ obsahu jednoho roku pred instalací a jednoho roku po instalaci. A z tohoto výběru bylo analyzováno, jakým způsobem opatření ovlivnilo bezpečnost daného přechodu pro chodce. Př́nos opatření byl porovnáván jen z hlediska počtu dopravních nehod a také dle okolností, které $\mathrm{k}$ nehodě přispěly.

Všechny přechody pro chodce, které byly realizovány $v$ období roků 2010-2012 byly podrobeny statistické analýze dopravní nehodovosti před a po realizaci.

$\mathrm{Na}$ všech z 87 přechodů se stalo celkem 7 dopravních nehod před realizací a 4 dopravní nehody po realizaci. Toto množství dopravních nehod je statisticky nevýznamné a z tohoto důvodu nebyly prováděny další testy.

Tabulka 1. Dopravní nehody na a v blízkosti sledovaných přechodu pro chodce

\begin{tabular}{|c|c|c|c|}
\hline \multirow{2}{*}{ Kritérium } & & \multicolumn{2}{|c|}{ V noci } \\
\cline { 3 - 4 } & Možnosti & Před & Po \\
\hline Počet & DN & 7 & 4 \\
\hline \multirow{2}{*}{ Vina } & Řidič & 5 & 3 \\
& Chodec & 2 & 1 \\
\hline \multirow{3}{*}{ Následky } & Bez zranění & 1 & 1 \\
& Zranění & 6 & 2 \\
& Smrt & 0 & 1 \\
\hline \multirow{3}{*}{ Povrch } & Suchý & 4 & 0 \\
& Mokrý & 2 & 2 \\
& Sníh & 1 & 2 \\
\hline \multirow{2}{*}{ Viditelnost } & S VO & 7 & 4 \\
& Bez VO & 0 & 0 \\
\hline \multirow{2}{*}{ Smyk } & Ano & 0 & 0 \\
& Ne & 7 & 4 \\
\hline
\end{tabular}

V Tabulce 1 je popsáno, při jakých podmínkách docházelo $\mathrm{k}$ dopravním nehodám. Ve většině případů je zavinění dopravní nehody přisuzováno řidiči motorového vozidla. Ani $u$ jedné $z$ dopravních nehod nedošlo ke smyku vozidla. Toto zjištění predikuje bud' to náraz v plné rychlosti, bez brždění a jakékoli reakce řidiče, nebo před srážkou byla rychlost velmi malá a nedošlo ke smyku. Ve všech prípadech byla komunikace osvětlena veřejným osvětlením. K dopravním nehodám po realizaci přisvětlení přechodu pro chodce docházelo za zhoršených povětrnostních podmínek kdy ani $v$ jednom $z$ prípadů, nebyla vozovka $v$ místě srážky suchá. Vlivem povětrnostních podmínek byla ovlivněna také dopravní nehoda s úmrtím chodce, která se stala za sněžení na kluzké vozovce.

\section{Odraznost chodců}

Důležitý parametr pro bezpečnost chodců na silnici je odraznost jejich oděvů či doplňků. Lidské oko vnímá kontrasty jasů předmětů. Výše jasů je závislá na odraznosti materiálu oblečení a dopadajícím světelném toku, tedy osvětlenosti oblečení chodce.

Jas dokonale rozptylně odrážející plochy nezávisí na úhlu dopadu světelných paprsků. $\vee$ praxi ovšem neexistují ideální rozptylovače. $U$ většiny povrchů vzniká smíšený odraz. Při světelně technických výpočtech se nejčastěji využívá vlastností ideálně rozptýlené plochy, nebot' se tím výpočty podstatně zjednoduší. Pro analýzu činitele odrazu oděvů náhodných chodců je toto zjednodušení využito. Jde především o tkaniny, které se vlastnostem ideálního rovnoměrného rozptylovače velice bliží. Chyba, která se při výpočtech vyskytne, je akceptovatelná, nebot' jde především o měření, které má přiblížit danou problematiku.

$$
\rho=\frac{\pi \cdot \mathrm{L}}{E}
$$

Měření se zúčastnilo 28 osob, které byly náhodně vybrány z chodců jdoucích po ulici. Z tohoto počtu bylo 17 osob mužů a 11 osob byly ženy. Průměrný věk figurantu byl 31 let. Nejstarší účastník měl 71 let a nejmladší 1 rok.

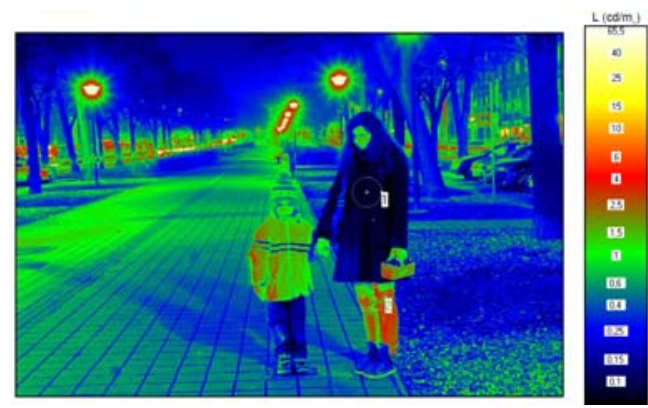

Obr.1. Jasová analýza měřené osoby 
Tabulka 2. Tabulka vypočtených hodnot odrazných vlastností chodců

\begin{tabular}{|c|c|c|c|c|c|}
\hline \multicolumn{2}{|c|}{ PRŮMĚRNÉ HODNOTY: } & MEDIÁN & $\min$ & $\max$ \\
\hline \multicolumn{2}{|c|}{ VĚK } & 31 & 30 & 1 & 71 \\
\hline \multicolumn{2}{|c|}{ M - muži } & 29 & 27 & 3 & 57 \\
\hline \multicolumn{2}{|c|}{ Z - ženy } & 33 & 31 & 1 & 71 \\
\hline \multirow{3}{*}{$\begin{array}{c}\text { Jas } \\
\left(\mathrm{cd} / \mathrm{m}^{2}\right)\end{array}$} & NAHOŘE & 0,55 & 0,23 & 0,09 & 3,30 \\
\cline { 2 - 6 } & DOLE & 0,37 & 0,25 & 0,08 & 2,25 \\
\cline { 2 - 6 } & CELKEM & 0,46 & 0,23 & 0,08 & 3,30 \\
\hline \multirow{3}{*}{ Odraz } & NAHOŘE & $15,7 \%$ & $6,6 \%$ & $2,5 \%$ & $94,1 \%$ \\
\cline { 2 - 6 } & DOLE & $10,7 \%$ & $7,2 \%$ & $2,3 \%$ & $64,2 \%$ \\
\cline { 2 - 6 } & CELKEM & $13,2 \%$ & $6,6 \%$ & $2,3 \%$ & $94,1 \%$ \\
\hline
\end{tabular}

Hodnoty odrazností oděvů se pohybovaly $v$ rozmezí od $2,3 \%$ (černé kalhoty) do 94,1 \% (reflexní bunda). Medián odrazností byl vypočíán na hodnotu 6,6 \%.

Téměř ukázkovým prípadem je figurant číslo 15. Odraznost horní části oblečení je $7 \%$ a dolní části $5 \%$. Což je $\mathrm{z}$ hlediska viditelnosti nevhodné.

= NAHOŘE $=$ DOLE

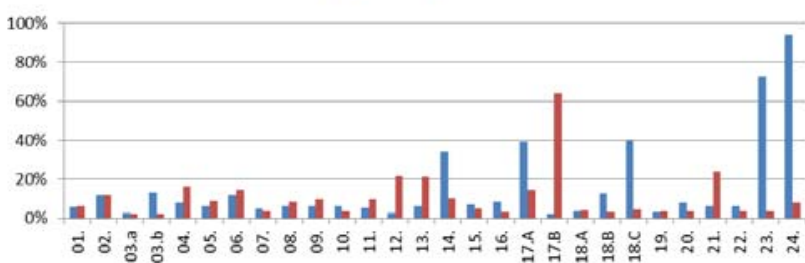

Obr.2. Graf odrazností oděvu chodců

Na Obr. 2 je znázorněno, že odraznost oděvů chodců byla opravdu velice nízká. Jen několik málo případů vykazuje odraznost vyšší než $20 \%$. Takto málo světlé oděvy snižují viditelnost chodce a zvyšují tak nebezpečí přehlednutí chodce řidičem i na osvětleném přechodu pro chodce.

$V$ literatuře se setkáváme $s$ údaji o průměrné odraznosti $v$ teorii fotografie, kde je uváděno, že žijeme ve světě, který je $v$ průměru šedivý, osmnáctiprocentní šedivý.

Při výstavbě přechodu pro chodce a jeho přisvětlení je řešena problematika $z$ několika pohledů. Je nutné respektovat legislativní požadavky jak na samotnou výstavbu, tak na řešení osvětlovací soustavy. Přechod pro chodce by měl být vystavěn $v$ místě, kde je možné bezpečné přejití vozovky s dobrými rozhledovými parametry a doplněn přisvětlením pro zlepšení viditelnosti chodce $v$ nočních hodinách jak pro chodce, tak pro řidiče. Je nutné, aby chodci dbali na svou bezpečnost a užívali přechod pro chodce na vyznačeném úseku a také používali oblečení ze světlejších materiálů, prípadně nosili reflexní doplňky - viz. naměřené nízké hodnoty odrazností.

\section{Jasové pomèry - jas pozadí}

Stejně důležitý parametr jako odraznost oděvu chodce je i jas pozadí. Při vysokých jasech pozadí se nedoporučuje používat přisvětlení chodců, nebot' by zvýšení jasu oděvu chodce vedlo k vyrovnání jasového poměru a snížení viditelnosti chodce. Proto při navrhování osvětlovací soustavy pro přisvětlení přechodu pro chodce musíme vycházet i z jasu pozadí.

Při měření byly vyhodnocovány tř̆i oblasti. Jas pozadí nástupu, jas pozadí v prostoru přechodu a jas pozadí nástupního místa v protisměru, případně ostrůvku.
Pokud byla minimální hodnota nižší než hodnota dolní meze vnitřní hradby nebo byla maximální hodnota vyšší než hodnota horní meze vnitřní hradby, byl jas nástupu vyhodnocen jako medián. $V$ jiných prrípadech jako aritmetický prưmèr.(viz. statistické vyhodnocování)

Naměřená data byla použita z měření 87 osvětlených přechodů pro chodce (174 objektů - tzn. 87 přechodů oboustranně) v Ostravě.

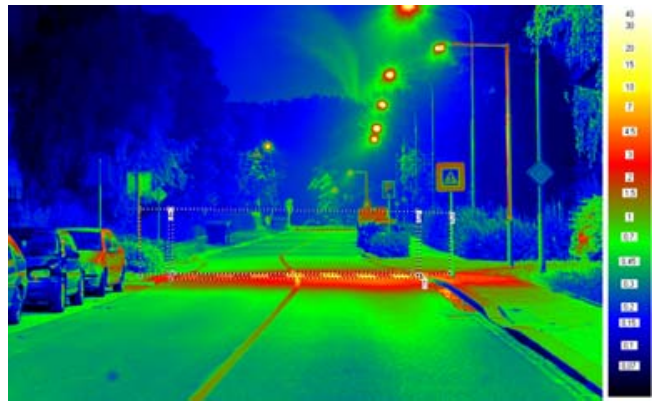

Obr.3 Prostory hodnocené jasovou analýzou

Tabulka 3. Tabulka vypočtený průměrných hodnot a mediánů pozadí

\begin{tabular}{|c|c|c|c|}
\hline \multicolumn{4}{|c|}{ Osvětlenost komunikace: } \\
\hline \multicolumn{2}{|c|}{ Počet objektů: } \\
\hline Parametr & $\begin{array}{c}\text { Nástup 1 } \\
\left(\mathrm{cd} / \mathrm{m}^{2}\right)\end{array}$ & $\begin{array}{c}\text { Pozadí 1 } \\
\left(\mathrm{cd} / \mathrm{m}^{2}\right)\end{array}$ & $\begin{array}{c}\text { Nástup 2 / } \\
\text { Ostrùvek } \\
\left(\mathrm{cd} / \mathrm{m}^{2}\right)\end{array}$ \\
\hline medián & $\mathbf{0 , 5}$ & $\mathbf{0 , 8}$ & $\mathbf{0 , 6}$ \\
\hline průměr & 1,0 & 1,1 & 1,2 \\
\hline min & 0,1 & 0,1 & 0,1 \\
\hline max & 28,2 & 12,6 & 21,0 \\
\hline
\end{tabular}

Z Tabulky 3 je zřejmé, že při hodnocení všech změřených přechodů pro chodce byly všechny tři oblasti hodnoceny jako mediány vlivem vzdálených pozorování. Při srovnání vypočtených hodnot je patrné, že jas pozadí je vyšší než jas nástupů (ostrůvku). Bylo hodnoceno všech 174 měřených objektů.

Tabulka 4. Tabulka vypočtených průměrných hodnot a mediánů pozadí

\begin{tabular}{|c|c|c|c|}
\hline \multicolumn{3}{|c|}{ Osvětlenost komunikace: } & $\mathrm{E}<10 \mathrm{~lx}$ \\
\hline \multicolumn{2}{|c|}{ Počet objektů: } & 70 \\
\hline Parametr & $\begin{array}{c}\text { Nástup 1 } \\
\left(\mathrm{cd} / \mathrm{m}^{2}\right)\end{array}$ & $\begin{array}{c}\text { Pozadí 1 } \\
\left(\mathrm{cd} / \mathrm{m}^{2}\right)\end{array}$ & $\begin{array}{c}\text { Nástup 2 / } \\
\text { Ostrůvek } \\
\left(\mathrm{cd} / \mathrm{m}^{2}\right)\end{array}$ \\
\hline medián & $\mathbf{0 , 5 0}$ & $\mathbf{0 , 7 0}$ & $\mathbf{0 , 4 8}$ \\
\hline průměr & 0,52 & 0,74 & 1,16 \\
\hline min & 0,1 & 0,1 & 0,1 \\
\hline max & 1,6 & 2,0 & 1,7 \\
\hline
\end{tabular}

Z Tabulky 4 je zřejmé, že při hodnocení změřených přechodů pro chodce shorizontální osvětleností okolí přechodu v rozsahu osvětleností $E<101 x$ byly všechny tři oblasti hodnoceny jako mediány vlivem vzdálených pozorování. Při srovnání vypočtených hodnot je patrné, že jas pozadí je vyšší než jas nástupů (ostrůvku). Bylo hodnoceno 70 měřených objektů z celkového počtu 174. 
Tabulka 5 Tabulka vypočtených průměrných hodnot a mediánů pozadí

\begin{tabular}{|c|c|c|c|}
\hline \multicolumn{2}{|c|}{ Osvětlenost komunikace: } & \multicolumn{3}{c|}{ 10lx $>\mathrm{E}<201 \mathrm{x}$} \\
\hline \multicolumn{2}{|c|}{ Počet objektů: } \\
\hline Parametr & $\begin{array}{c}\text { Nástup 1 } \\
\left(\mathrm{cd} / \mathrm{m}^{2}\right)\end{array}$ & $\begin{array}{c}\text { Pozadí 1 } \\
\left(\mathrm{cd} / \mathrm{m}^{2}\right)\end{array}$ & $\begin{array}{c}\text { Nástup 2 / } \\
\text { Ostrůvek } \\
\left(\mathrm{cd} / \mathrm{m}^{2}\right)\end{array}$ \\
\hline medián & $\mathbf{0 , 4 0}$ & $\mathbf{0 , 7 0}$ & $\mathbf{0 , 5 3}$ \\
\hline průměr & 0,60 & 0,99 & 1,08 \\
\hline min & 0,1 & 0,1 & 0,1 \\
\hline max & 3,2 & 6,3 & 21,0 \\
\hline
\end{tabular}

Z Tabulky 5 je zřejmé, že při hodnocení změřených přechodů pro chodce shorizontální osvětleností okolí přechodu v rozsahu osvětleností $101 x>E<201 x$ byly všechny tři oblasti hodnoceny jako mediány vlivem vzdálených pozorování. Při srovnání vypočtených hodnot je patrné, že jas pozadí je vyšší než jas nástupů (ostrůvku). Hodnoty pozadí nástupních prostorů a pozadí samotného přechodu jsou totožné jako při vyhodnocování přechodů pro chodce $v$ rozsahu horizontálních osvětleností okolí přechodu $E<101 x$. Bylo hodnoceno 70 měřených objektů z celkového počtu 174 .

Tabulka 6 Tabulka vypočtených průměrných hodnot a mediánů pozadí

\begin{tabular}{|c|c|c|c|}
\hline \multicolumn{3}{|c|}{ Osvětlenost komunikace: } & $201 x>E<301 x$ \\
\hline \multicolumn{3}{|c|}{ Počet objektů: } & 21 \\
\hline Parametr & $\begin{array}{l}\text { Nástup } 1 \\
\left(\mathrm{~cd} / \mathrm{m}^{2}\right)\end{array}$ & $\begin{array}{c}\text { Pozadí } 1 \\
\left(\mathrm{~cd} / \mathrm{m}^{2}\right)\end{array}$ & $\begin{array}{l}\text { Nástup } 2 \text { I } \\
\text { Ostrůvek } \\
\left(\mathrm{cd} / \mathrm{m}^{2}\right)\end{array}$ \\
\hline medián & 1,00 & 1,56 & 1,20 \\
\hline průměr & 1,14 & 2,36 & 1,39 \\
\hline $\min$ & 0,2 & 0,4 & 0,2 \\
\hline $\max$ & 5,1 & 12,6 & 4,2 \\
\hline
\end{tabular}

Z Tabulky 6 je zřejmé, že při hodnocení změřených přechodů pro chodce shorizontální osvětleností okolí přechodu v rozsahu osvětleností $201 x>E<301 x$ byly všechny tři oblasti hodnoceny jako mediány vlivem vzdálených pozorování. Při srovnání vypočtených hodnot je patrné, že jas pozadí je vyšší než jas nástupů (ostrůvku). Hodnoty pozadí nástupních prostorů a pozadí samotného přechodu jsou vyšší jako při vyhodnocování předchozích skupin přechodů pro chodce. Bylo hodnoceno 21 měřených objektů z celkového počtu 174.

Z Tabulky 7 je zřejmé, že při hodnocení změřených přechodů pro chodce shorizontální osvětleností okolí přechodu v rozsahu osvětleností $30 \mathrm{~lx}>\mathrm{E}<50 \mathrm{~lx}$ byla oblast nástupního místa vpravo z pohledu přijíždějícího rridiče hodnocena jako medián vlivem vzdálených pozorování. Datový soubor dalších dvou oblastí nevykazoval vzdálená pozorování, proto mohly být tyto oblasti hodnoceny jako aritmetické průměry. Při srovnání vypočtených hodnot je patrné, že jas pozadí je vyšší než jas nástupů (ostrůvku). Hodnoty pozadí nástupních prostorů a pozadí samotného přechodu jsou vyšší jako při vyhodnocování předchozí skupiny prechodů pro chodce. Bylo hodnoceno 11 měřených objektů z celkového počtu 174 .
Tabulka 7 Tabulka vypočtených průměrných hodnot a mediánů pozadí

\begin{tabular}{|c|c|c|c|}
\hline \multicolumn{3}{|c|}{ Osvětlenost komunikace: } & $301 x>E<501 x$ \\
\hline \multicolumn{3}{|c|}{ Počet objektů: } & 11 \\
\hline Parametr & $\begin{array}{l}\text { Nástup } 1 \\
\left(\mathrm{~cd} / \mathrm{m}^{2}\right)\end{array}$ & $\begin{array}{c}\text { Pozadí } 1 \\
\left(\mathrm{~cd} / \mathrm{m}^{2}\right)\end{array}$ & $\begin{array}{l}\text { Nástup 2 / } \\
\text { Ostrůvek } \\
\left(\mathrm{cd} / \mathrm{m}^{2}\right)\end{array}$ \\
\hline medián & 1,00 & 1,90 & 1,40 \\
\hline průmèr & 0,95 & 1,97 & 1,47 \\
\hline $\min$ & 0,2 & 0,8 & 0,6 \\
\hline $\max$ & 1,6 & 3,0 & 3,0 \\
\hline
\end{tabular}

Tabulka 8 Tabulka vypočtených průměrných hodnot a mediánů pozadí

\begin{tabular}{|c|c|c|c|}
\hline \multicolumn{3}{|c|}{ Osvětlenost komunikace: } & E > 501x \\
\hline \multicolumn{3}{|c|}{ Počet objektů: } \\
\hline Parametr & $\begin{array}{c}\text { Nástup 1 } \\
\left(\mathrm{cd} / \mathrm{m}^{2}\right)\end{array}$ & $\begin{array}{c}\text { Pozadí 1 } \\
\left(\mathrm{cd} / \mathrm{m}^{2}\right)\end{array}$ & $\begin{array}{c}\text { Nástup 2 / } \\
\text { Ostrůvek } \\
\left(\mathrm{cd} / \mathrm{m}^{2}\right)\end{array}$ \\
\hline medián & 5,05 & 4,70 & 9,65 \\
\hline průměr & $\mathbf{5 , 0 5}$ & $\mathbf{4 , 7 0}$ & $\mathbf{9 , 6 5}$ \\
\hline min & 4,7 & 4,3 & 5,4 \\
\hline max & 5,4 & 5,1 & 13,9 \\
\hline
\end{tabular}

Z Tabulky 8 je zřejmé, že při hodnocení změřených přechodů pro chodce s horizontální osvětleností okolí přechodu v rozsahu osvětleností $E>50 l x$ nebyla žádná oblast hodnocena jako medián vlivem vzdálených pozorování. Datové soubory všech tři oblastí nevykazoval vzdálená pozorování, a proto mohly být tyto oblasti hodnoceny jako aritmetické průměry. Při srovnání vypočtených hodnot je patrné, že jas pozadí je nižší než jas nástupů (ostrůvku). Byly hodnoceny pouze dva měřené objekty z celkového počtu 174. Takto nízký počet je statisticky nevýznamný a nelze tedy $z$ těchto údajů usuzovat závěry ohledně jasu pozadí. $Z$ daného počtu Ize však usoudit, že přechody $s$ takto vysokou horizontální osvětleností okolí se měřené oblasti vyskytuji jen zrrídka.

\section{ZÁVĚR}

Experiment analyzující poměrnou odraznost oděvů chodců prokázal, že vypočtené hodnoty poměrné odraznosti oděvů posuzovaných chodců jsou velice nízké. Chodci by měli dbát na svou vlastní viditelnost používáním světlejších oděvů, případně reflexních doplňků.

Při analyzování jasových poměrů bylo na 87 osvětlených přechodech pro chodce ukázáno, že jas pozadí přechodu je vyšší než jas pozadí nástupních ploch. Díky ověření tohoto předpokladu lze osvětlovat nástupní místa na nižší hodnoty svislé osvětlenosti než samotnou část přechodu - jak plyne z [10] Z dat také vyplynulo, že ověřovaný předpoklad nebyl splněn $u$ všech posuzovaných přechodů a proto je nutné k osvětlování přechodi̊ pro chodce přistupovat individuálně.

\section{PODĚKOVÁNÍ}

Tento článek byl vypracován za podpory projektu " Přenos řídících signálů v osvětlovacích soustavách“. SP2015/182

\section{ZDROJE}

[1] Český statistický úr̆ad [online].

Dostupné $\mathrm{z}$ URL <http://www.czso.cz/csu/redakce.nsf/i/doprava_a _spoje>. 
[2] BESIP [ONLINE].

Dostupné z

URL

<http://www.ibesip.cz/cz/statistiky/ statistikynehodovosti-v-ceske-republice/dopravninehodovost-v-roce-2012/chodci $>$.

[3] LITSCHMANNOVÁ, M.: Úvod do statistiky, Ostrava 2011 VŠB - TU Ostrava, Fakulta elektrotechniky a informatiky.

[4] BRIŠ R., LITSCHMANNOVÁ M. Statistika I. pro kombinované a distanční studium [online]. c2004., Dostupné z URL <www.am.vsb.cz/litschmannova>.

[5] Geografický informační systém Jednotná dopravní vektorová mapa [online].

Dostupné $z \quad$ URL http://www.jdvm.cz/cz/s477/Rozcestnik/c7315Statistika-nehod-v-mape>.

[6] BLÁHA, Z. Řešení VO v konfliktních oblastech. In sborník Kurz osvětlovací techniky XXIX Ostrava, 2012, ISBN 978-80-248-2832-9.

[7] Observatoř bezpečnosti silničního provozu [online].

Dostupné

<http://www.czrso.cz/clanky/dopravneinzenyrska-data-v-ceskem-prostredi-analyzadostupnosti-rozsahu-a-pouzitelnosti/>.
[8] HABEL, J. - DVOŘÁČEK, K. - DVOŘÁČEK, V. ŽÁK, P., Světlo a osvětlování, FCC PUBLIC, Praha, 2013, 624 p, ISBN 978-80-86534-21-3.

[9] MAIXNER, T. Osvětlení přechodů pro chodce. SVĚTLO, leden 2012 roč. 15. č.1. ISSN 12120812 .

[10]Technické kvalitativní podmínky staveb pozemních komunikací, kapitola 15, Osvětlování pozemních komunikací, Dodatek č. 1 Přisvětlování přechodủ. Připravovaná revize TKP $z$ roku 2006. Ministerstvo dopravy, obor infrastruktury.

[11]ČSN EN12464-2 Světlo a osvětlení - Osvětlení pracovních prostorů - Cást 2: Venkovní pracovní prostory, Česká technická norma, červenec 2007

Authors: Ing. Zdeněk Bláha, prof. ing. Karel Sokanský, CSc., Ing. Tomáš Novák Ph.D. Vysoká škola báňská - Technická univerzita Ostrava Fakulta elektrotechniky a informatiky, 17. Listopadu 15/2172, Czech Republic, e-mail zdenek.blaha@vsb.cz: karel.sokansky@vsb.cz, tomas.novak1@vsb.cz 